\title{
TINJAUAN MUKHTALAF AL-HADÎTS TERHADAP HADITS-HADITS MENANGISI MAYIT
}

\author{
Komarudin \\ Mahasiswa Pasca Sarjana Universitas Islam Syarif Hidayatullah Jakarta \\ Jln. Ir. H. Juanda No 95 Ciputat Tanggerang Selatan \\ Email: komarudinmasyhur@yahoo.com
}

\begin{abstract}
Mukhtalaf al-Hadits contemplation to al-Haditts on crying the corpse. This article is aimed to explain the answer of Islamic jurisprudence towards law of the bewailing for cadaver (dead person's body). Some moslem communities assume that bewailing for cadaver is lawful. It is common that everyone will fill sad when he or she losses the family member. Others assume that it is unlawful. Bewailing for cadaver can make the corpse be punished. The others assume it is allowed when the crying is not over but not allowed when the the crying is normal. Islam jurisprudence has a theory to solve such a case. It is called Mukhtalaf al-Haditts. This article also explain Mukhtalaf al-Hadits role in explaining on bewailing for cadaver.
\end{abstract}

Keyword: Bewailing for Cadaver, Islamic law, Hadîts

Abstrak: $\quad$ Tinjauan Mukhtalaf Al-Hadîts Terhadap Hadits-Hadits Menangisi Mayit. Artikel ini ditujukan untuk menjelaskan jawaban hukum Islam terhadap hukum menagisi mayit. Sebagian masyarakat muslim menggangap bahwa menangisi mayit adalah hal yang biasa karena siapapun akan merasa sedih jika kehilangan anggota keluarga. Sebagian lainnya menganggap bahwa menangisi mayit adalah tidak dibolehkan karena hal tersebut bisa menyebabkan mayit akan diazab. Ada juga yang beranggapan bahwa menangisi mayit diperbolehkan selagi tangisan tersebut tidak berlebihan dan tidak memperbolehkan jika tangisan tersebut berlebihan. Hukum Islam memiliki teori dalam menyelesaikan problematika di atas yang dikenal dengan Mukhtalaf al-Hadits. Artikel ini juga menjelaskan peran Mukhtalaf al-Hadîts dalam menjelaskan hukum menangisi mayit.

Kata kunci: Menangisi Mayit, Hukum Islam, Hadîts

\section{Pendahuluan}

Sebagai sumber ajaran Islam setelah Al-Quran, Hadits Nabi memuat berbagai aspek kehidupan manusia, mulai dari hal yang paling kecil hingga kepada hal yang paling bersar. Sebagian hadits nabi memiliki kandungan 
yang sederhana sehingga mudah dipahami. Namun tidak sedikit hadits yang memuat berbagai persoalan yang pelik dan sukar dipahami. Kepelikan dan kesukaran tersebut tidak hanya secara nalar tetapi juga persoalan yang saling bertentangan antara satu hadits dengan hadits lainnya. Pengaruh keberadaan hadits yang saling bertengtangan satu dengan lainnya akan menyebabkan pada kesimpulan hukum yang pincang jika tidak dipahami sesuai rambu-rambu ilmu hadits.

Sering dijumpai di suatu masyarakat seseorang yang menghardik keluarga mayit yang sedang menangis dengan alasan jika mayit ditangisi maka si mayit akan disiksa di dalam kubur. Namun ada juga seseorang yang menganggap tangisan seseroang terhadap anggota keluarga yang ditinggalkan adalah hal yang wajar.

Dalam perspektif ilmu hadits, jenis hadits yang saling bertentangan tersebut dikenal dengan mukhtalif al-hadîts. ${ }^{1}$ Pada tulisan ini penulis mengangkat salah satu dari jenis hadits tersebut yang berkaitan dengan hukum menangisi mayat/janazah yang kemudian hadits tersebut ditinjau menurut mukhtalif al-hadîts. Maka rumusan masalah yang diharapkan terjawab adalah (1) apa yang dimaksud dengan mukhtalif al-hadîts?, (2) apa saja hadits-hadits yang berkaitan dengan menangisi mayit?, dan (3) bagaimana hukum menangisi mayit?

\section{Mukhtalaf al-Hadîts}

Secara etimologi, mukhtalaf al-Hadîts adalah susunan idlâfî dari 'mukhtalaf dan 'al-hadîts'. Mukhtalaf diambil dari kata ikhtalafa-yakhtalifuikhtilaff yang berarti 'membuat sesuatu menjadi di belakang'2 Hadits adalah segala sesuatu yang disandarkan kepada Nabi Muhammad SAW baik perkataann, perbuatan, persetujuan, atau ketetapannya. ${ }^{3}$

\footnotetext{
${ }^{1}$ 'Abd al-Majîd Muhammad Ismâil al-Sawsûh, Manhaj al-Taufì wa al-Tarjîh baina Mukhtaîif al-Hadîts,(Dar al-Nafais, t.t.), h. 21

${ }^{2}$ Lois Malûf, al-Munjid fî al-Lughah wa al-I'lâm, (Bairut: Da al-Masyriq, 1982), cet. ke-28, h. 192

${ }^{3}$ Menurut Ibn Taymiyyah, hadits nabi adalah segala perkataan, perbuatan, dan ketetapan nabi saw setelah masa kenabian. Lihat Taqî al-Dîn Ibn Taymiyyah, 'Ilm al-Hadits, (Bairût: Dâr alKutub al-Ilmiyyah, 1409 H/1989 M), cet. ke-III, h. 5. Selain kata 'hadits', kata yang sepadan yang digunakan untuk istilah yang sama adalah 'sunnah'. Secara etimologi 'sunnah' berarti 'perjalanan yang baik atau perjalanan yang buruk'. Pengertian etimologi ini didasari atas sabda nabi saw:

من سن في الاسلام سنة حسنة فله أجراخا و أجر من عمل بها من بعده من غبر ان ينقص من أجورهم شيئا و من سن . Pن
} 
Secara terminologi terdapat beberapa pengertian mukhtalaf al-hadîts. Menurut Imam Syafii, dua hadits tidak dapat disebut ikhtilâf (bertengangan) selama ada sisi yang memungkinkan kandungan keduanya dapat berlaku. Menurut Ibn Hajar, hadîts maqbûl yang tidak bertengangan dengan hadits lainnya maka dapat dijadikan hujjah. Jika bertentangan dengan hadîts maqbûul lainnya dan ada peluang untuk dikompromikan keduannya maka ia disebut Mukhtalif al-Hadîts. Menurut Syaraf alQudhat, Mukhtalif al-Hadîts adalah ilmu yang membahas pertentangan hadits dengan hadits lain, dengan al-Quran, logika, dan fakta. ${ }^{4}$

Contoh hadits yang bertentangan dengan al-Quran adalah hadits yang diriwayatkan oleh al-Thahawi dengan sanadnya dari 'Abd al-Rahman bin Syabl berkata:

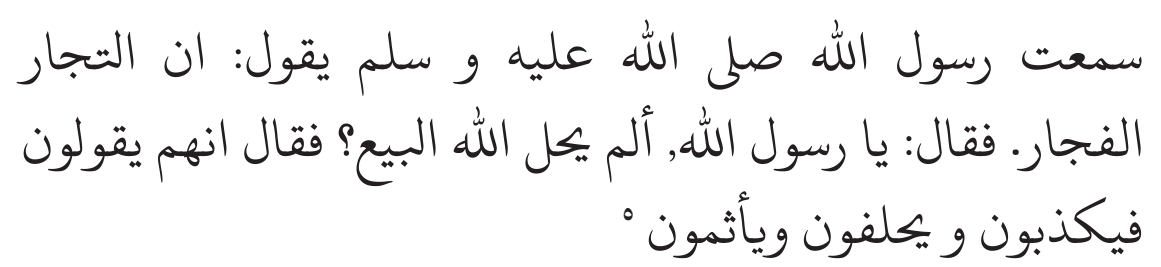

"Saya mendengar Rasulullah saw bersabda: sesungguhnya para pedagang itu adalah para pembuat dosa. Ditanyakan kepada beliau: Wahai Rasulullah, bukankah Allah telah menghalalkan berdagang? Beliau menjawab: mereka berkata tetapi berbohong dan berbuat dosa"

Hadits tersebut menimbulkan pamahaman bahwa berdagang merupakan perbuatan dosa sehingga pedagang dinilai sebagai pendosa. Hal ini bertentangan dengan firman Allah SWT:

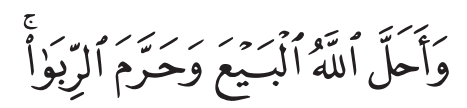

"Dan Allah menghalalkan perdagangan dan mengharamkan riba" (Q.S. Al-Baqarah 2: 275)

$$
\text { في الاسلام سنة سيئة كان عليه وزرها و وزر من عمل بها من بعده من غير أن ينقص من أوزارهم شيئا }
$$

lihat, Muhammad bin Mathar al-Zahrânî, Tadwîn al-Sunnah al-Nabawiyyah Nawyatuhu wa Tathawwuruhû min al-Qarn al-Awwal ila Nihâyah al-Qarn al-Tâsi' al-Hijrî, (al-Madînah alNabawiyyah: Dâr al-Khudlairî, 1419 H/1998 M), cet. ke-II, h. 14. Lihat juga Musthafâ al-Sib'î, AlSunnah wa Makânuhâ fi al-Tasyri al-Islâmî, (Bairut: Dâr al-Warrâq, 1419H/ 1998 M), cet. ke-I, h. 65

${ }^{4}$ Syaraf al-Qudhât, 'Ilm Mukhtalif al-Hadîts; Ushuluhîu wa Qawẩiduhûu, (Amman: al-Jami'ah al-Urduniyyah, 2001), h. 7

${ }^{5}$ Al-Thahâwî, Syarh Musykil al-Atsâr, (Bairut: Dâr -Kutub al-Ilmiyyah, 1995), cet. ke-I, h. 9 
Contoh hadits yang bertentangan dengan realita adalah hadits yang diriwayatkan oleh al-Thahawi dari 'Ibn 'Umar ra bahwa Rasulullah saw bersabda:

"Sesungguhnya orang kafir makan dalam tujuh perut sedangkan orang muslim makan dalam satu perut"

Hadits tersebut bertentangan dengan realita karena orang muslim tidak makan dengan tujuh perut. Sesungguhnya hadits tersebut pemahaman bahwa orang muslim membaca basmallah saat makan sehingga ada berkah dalam makanannnya. Sedangkan orang kafir tidak membaca basmallah saat makan sehingga tidak ada barakah dalam makanannya. ${ }^{6}$

Walaupun ada pengertian dan pemahaman istilah Mukhtalif al-Hadìts namun sesungguhnya hakikat pertentangan antara satu hadits dengan lainnya tidak ada. Hadits nabi terbebas dari segala cacat dan terhindar dari kesalahpahaman kahrena ucapan-ucapan Nabi juga merupakan wahyu Allah SWT. Hal ini sejalan dengan firman Allah SWT,

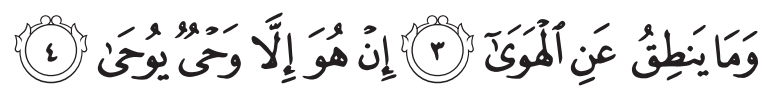

"Dan tidaklah yang dicuapkannya menurut hawa nafsu, ucapannya itu tiada lain hanyalah wahyu yang diwahyukan (kepadanya)" (Q.S. An-Najm3-4 :53 )

Ibn Huzamah mengatakan bahwa tidak kada hadits yang bertentangan. Jika engkau menemukan pertentangan maka datanglah kepadaku agar aku kompromikan kedua hadits yang bertentangan itu. Oleh karena itu jumhur berpendapat tidak ada pertentangan secara hakiki. $^{7}$

Menurut al-Nawawi, Mukhtalif al-Hadîts adalah dua hadits yang zhahirnya saling bertentangan namun dapat dikompromikan atau salah satu dari yang dua tersebut dikuatkan. ${ }^{8}$

${ }^{6}$ Al-Thahâwî, Syarh Musykil al-Atsâr, h.9

7 'Abd al-Majîd Muhammad Ismâ'îl al-Sausuwah, Manhaj al-Taufìq wa al-Tarjîh bain alMukhtalif al-Hadîts wa Atsaruhî fi Figh al-Islâmî, (Kairo: Jâmi’ah al-Qâhirah, 1992, h. 71

${ }^{8}$ Ibn Syaraf al-Nawâwî, Taqrîb 'Ulùm al-Hadîts (dengan catatan kaki Tadrîb al-Râwî), (AlMaînah: al-Maktabah al-'Ilmiyyah, 1972), cet. ke-II, jilid ke-II, h. 197 


\section{Syarat-syarat Mukhtalaf}

Keadaan saling bertentangan antara satu hadits dengan hadits lainnya tidak dapat terwujud kecuali terpenuhi hal-hal berikut ini: Pertama, Pertentangan terjadi dalam satu kontek permasalahan, jika terjadi dalam dua konteks yang saling berbeda, maka keduanya tidak dapat dianggap saling bertentangan. Kedua, Pertentangan antara dua hukum (madlûl) seperti yang satu menjelaskan sesuatu yang haram dan yang lainnya menjelaskan sesuatu yang halal. Ketiga, Kedua hadits yang bertentangan memiliki kualitas yang sama. Kempat, Pertentangan terjadi pada satu peristiwa. Misalnya hadits celaan terhadap saksi yang tidak jujur dengan hadits pujian bagi saksi yang jujur.?

\section{Sebab-sebab Mukhtalaf}

Pertentangan antara satu hadits dengan lainnya umumnya dilatarbelakangi oleh kesalahan periwayat, misalnya kesalahan hafalan dan periwayatan atau keterbatasan pemahaman terhadap hadits-hadits terkait. Berikut ini adalah beberapa sebab munculnya pertentangan antara hadits-hadtis.

\section{Sebab-sebab Ikhtilâf Zhâhirî}

Ikhtilaf Zhahiri terjadi disebabkan: Pertama, Minimnya pemahaman yang baik terhadap hadits Nabi SAW sehingga mudah mengatakan bahwa satu hadits bertentangan dengan hadits lainnya. Kedua, Terbatasnya akal manusia sehingga tidak semua hal dapat diketahui dan dipastikan. Keterbatasan itulah yang menjadikan penyebab beberapa hadits dianggap bertentangan dengan hadits lainnya ${ }^{10}$

\section{Sebab-sebab Ikhtilâf Haqîqî}

Yang dimaksud dengan ikhtilaf haqiqi adalah pertentangan tidak terjadi pada sumbernya (Nabi SAW) tetapi pada nasakh sharih. Berikut ini adalah sebab-sebab ikhtilaf haqiqi: (a) Nasakh dalam hukum syara; alnasikh selalu bertentangan dengan mansukh, baik nasakh sharikh maupun ghairu sharikh. (b) Perbedaan rawi dalam menghafal, misalnya para sahabat

\footnotetext{
9 'Abd al-Majîd Bairum, Ikhltilâf Riwâyat al-Hadîts wa Atsaruhûu fi Ikhtilâf al-Fuqahâ, (Amman: al-Jâmi'ah al-Urduniyyah, 1990), h. 167

${ }^{10}$ Syaraf al-Qudhât, Ilm Mukhtalif al-Hadîts; Ushuluhî wa Qawầiduhîu, (Ammân: al-Jâmi'ah al-Urduniyyah, 2001), h. 13
} 
bertanya tentang suatu hal kepada nabi SAW lalu Nabi SAW menjawab dan mereka menjawab sabda Nabi SAW yang merupakan jawaban atas pertanyaan tersebut. Namun mereka lupa dengan pertanyaannnya sehingga mereka memahami hadits secara umum yang pada akhirnya menjadi bertentangan dengan hadits lain. Sesungguhnya pertentangan tersebut tidak akan terjadi jika pertanyaan dan jawabannya sama-sama diketahui. Menurut Imam Syafi'i tekadang perawi hadits meriwayatkan hadits yang merupakan jawaban dari suatu pertanyaan yang ia tidak ketahui. ${ }^{11}$

\section{Perbedaan Cara Rawi dalam Meriwayatkan Hadits}

Perbedaan terjadi ketika seorang rawi meriwayatkan hadits secara lengkap dan rawi lainnya meriwayatkan hadits secara ringkas. Hal ini dikarenakan saat nabi menjelaskan suatu persoalan seorang perawi tidak datang atau tidak mendengar dari awal penjelasan Nabi sedangkan perawi lainnya datang dari awal dan mendengar seluruhnya penjelasan Nabi.

\section{Metode Penyelesaian Mukhtalif al-Hadîts}

Menurtu Abu Hanifa, penyelesaian hadits yang saling bertentangan adalah mengikuti uruta sebagai berikut; (1) al-Naskh, (2) al-Tarjih, (3) al-Jam'u, (4) al-Tawaqquflal-Tasaquth.

Menurut Imam Syafi'i dan kebanyakan ahli hadits, proseses penyelesaian Mukhtalif al-Hadîts adalah: Pertama, Al-Jam’u wa al-Taufîq, yaitu mempertemukan sesuatu yang bertentangan dan kemudian mengkompromikannya. Kedua, Naskh, metode ini digunakan jika memenuhi beberapa syarat. Yaitu: (a)Kedua dalil memiliki derajat hadits yang sama (b)Tidak dijumpai nasakh sharih, (c)Tidak bisa dikompormikan (d) Diketahui mana hadits yang muncul lebih awal dan mana hadits yang muncul belakangan; Ketiga, Al-Tarjih, yaitu mengambil salah satu dalil dan meninggalkan yang lainnya karena diyakini salah satu dalil terdapat kekeliruan di dalamnya. Kempat, Al-TawaqquflAl-Tasaquth, yaitu tidak mengambil kedua dalil yang saling bertentangan karena tidak bisa diselesaikan melalui kompromi, nasakh, atau tarjih. ${ }^{12}$

\footnotetext{
${ }^{11}$ Al-Syafi'i, al-Risâlah, (Bairût: Dar al-Kutub al-'Ilmiyyah, t.t.), h. 213

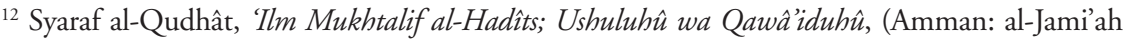
al-Urduniyyah, 2001), h. 25h
} 


\section{Hadits-hadits yang menyatakan mayat akan disiksa karena tangisan keluarga}

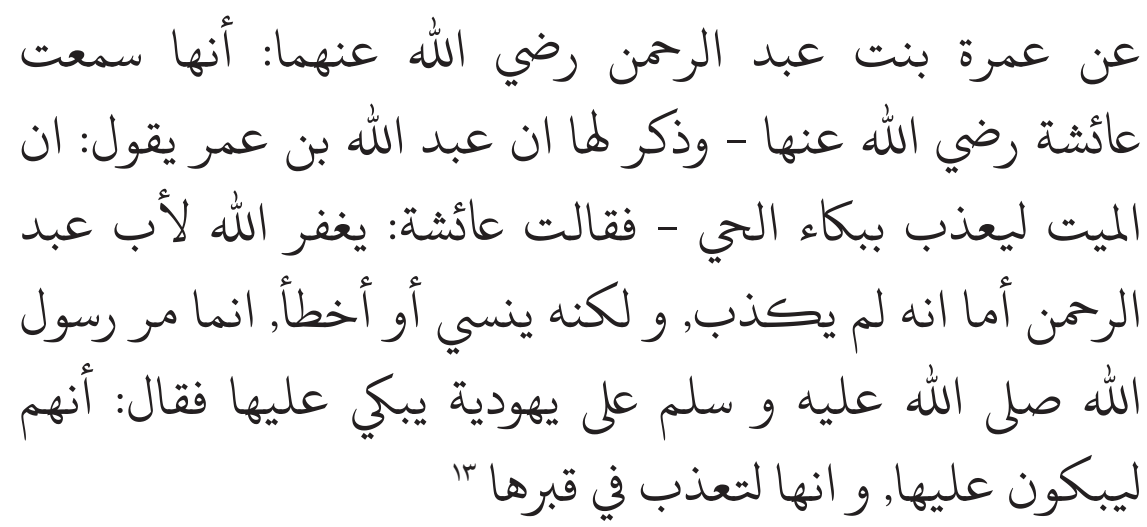

"Dari 'Amrah binti 'Abd al-Rahman -semoga Allah SWT meridlainyaSesungguhnya ia mendengar 'Aisyah ${ }^{14}$ r.a. dan ia mengingatkannya bahwa 'Abdullah bin 'Umar berkaa: Sesungguhnya mayit akan disiksa akibat tangisan orang yang masih hidup- maka 'Aisyah berkata: Allah mengampuni 'Abdul Rahman selagi ia tidak berdusta. Hanya saja dia lupa dan salah karena (saat) Rasulullah SAW melewati seorang yahudi yang menangisi (mayat)nya, ia bersabda: mereka menangisinya, maka kelak ia akan disiksa di dalam kuburnya” (HR Muslim)

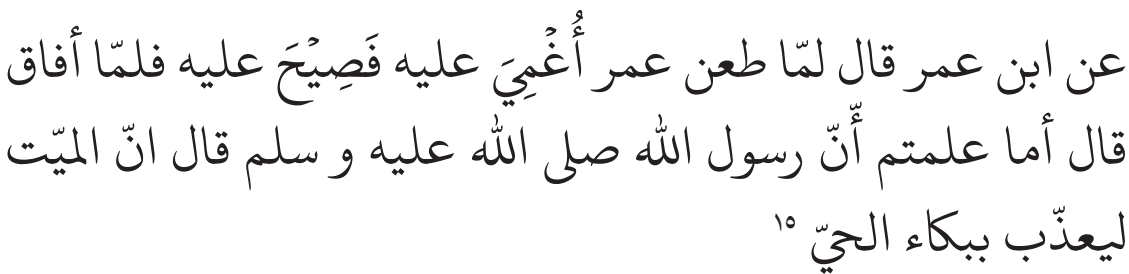

${ }^{13}$ Hâfidz al-Mundzirî, Mukbtashar Shahîh Muslim, Tahqîq: Muhammad Nâshir al-Dîn alBânî, (Wizârah al-Awqâf wa al-Syuûni al-Islâmiyyah al-Turats al-Islâmî, 1399 H/1979 M), cet. ke-III, h. 126

${ }^{14}$ Aisyah adalah putri Abû Bakr al-Shiddîq al-Taymiyyah, Ummu al-Mu’minîn, digelari dengan Ummu 'Abdillâh Ahli Fiqih (al-Faqîhah). Ibunya adalah Ummu Rûmân binti 'Uwaimir bin 'Abd al-Syams bin 'Inâb bin Udaynah bin Sabî' bin Dahmân bin al-Hârits bin Ghanam bin Mâlik bin Kinânah. Ia banyak meriwayatkan hadits dari Nabi saw, dari ayahnya sendiri, dari 'Umar, dari Hamzah bin 'Amr al-Aslamî bin Sảd bin Abî Waqqâsh, dari Jadâmah binti Wahab al-Asadî dan dari Fâthimah al-Zahrâ. Lihat Syihab al-Dîn Abu Fadhl Ahmad bin Hajar al-'Asqalânî, Tahdzîb al-Tahdzîb, (Bairut, Libanon: Dâr al-Ihyâ al-Turats al-Arabî, 1413 H/1993 M), cet. ke-VIII, jilid VI, h. 604

${ }^{15}$ Abu al-Husain Muslim bin al-Hajjâj al-Qusyairî al-Naisabûrî, Shahîh Muslim, (Bairût: Dâr al-Fikr, 1988), cet. ke-I, jilid I, h. 408 
"Dari Ibn Umar dia berkata, "ketika Umar ditusuk beliau tidak sadarkan diri [orang-orang menangis] sambil berteriak." Lalu saat ia sadar ia berkata, "apakah kalian tidak tahu bahwa Rasulullah pernah bersabda "sesungguhnya mayit akan diazab karena sebab tangisan orang yang masih hidup" (HR Muslim )

حدّثنا نافع عن عبد الله أنّ حفصة بكت على عمر فقال مهلا يا بنية ألم تعلم أنّ رسول الله صلى الله عليه و سلم قال انّ الميّيت

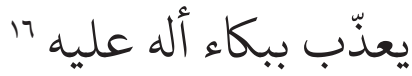

"Nafi bercerita kepada kami dari 'Abdillah bin 'Umar bahwa Hafshah menangisi 'Umar. Lalu 'Umar berkata: tenanglah wahai anakku, apakah engkau tidak tahu bahwa Rasulullah pernah bersabda bahwa mayat akan diazab karena keluarga menangisinya” (HR Muslim)

عن عبد الله بن عمر رضي الله عنهما قال: اشتكى سعد بن عبادة شَكُوَى له فأتاه النبي صلى الله عليه و سلم يعوده مع عبد الله بن الله عوف سعد بن أبي وقّاص و عبد الله بن مسعود رضي الله عنهم فلمّا دخل عليه وجده في غشيّةِ أهلِه فقال قَدَ قضى قالوال لا يا

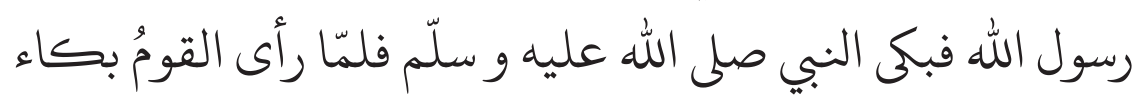

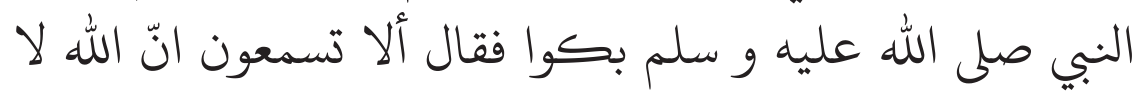
يعذّب بدمع العين و لا بحزن القلب و لكن يعذّب بهذا -و أشار iv

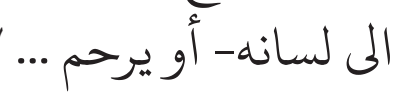

"Dari 'Abdullah bin 'Umar, dia berkata: ketika Sa'd bin 'Ubadah sakit, Rasulullah menjenguknya bersama dengan 'Abdul Rahman bin 'Auf, Sa'd bin Abi Waqqash, dan 'Abdullah bin Mas'ud. Ketika beliau menemuinya ternyata ia sedang dikerumuni keluarganya. Beliaupun

${ }^{16}$ Abu al-Husain Muslim bin al-Hajjâj al-Qusyairî al-Naisabûrî, Shahîh Muslim, h.408

${ }^{17}$ Abû 'Abdulâlh Muhammad bin Ismâîl, Shahîh al-Bukhârî, (Istanbul: Mausû'ah al-Sunnah; al-Kutub al-Sittah wa Syuruhuhâ, 1113 H/1992 M), cet. ke-II, jili ke-II, h. 85 
bertanya: apakah dia sudah wafat? Mereka menjawab' belum wahai Rasulullah. Kemudian Rasul menangis. Saat kerumunan orang melihat Rasul menangis, maka mereka menangis juga. Lalu Rasul bersabda: Apakah kalian tidak mendengar bahwa Allah SWT tidak akan mengazab disebabkan air mata dan sedihnya hati. Akan tetapi Allah akan mengazab disebabkan 'ini' dan Rasul mengisyaratkan kepada lidahnya" (HR. Bukhari dan Muslim)

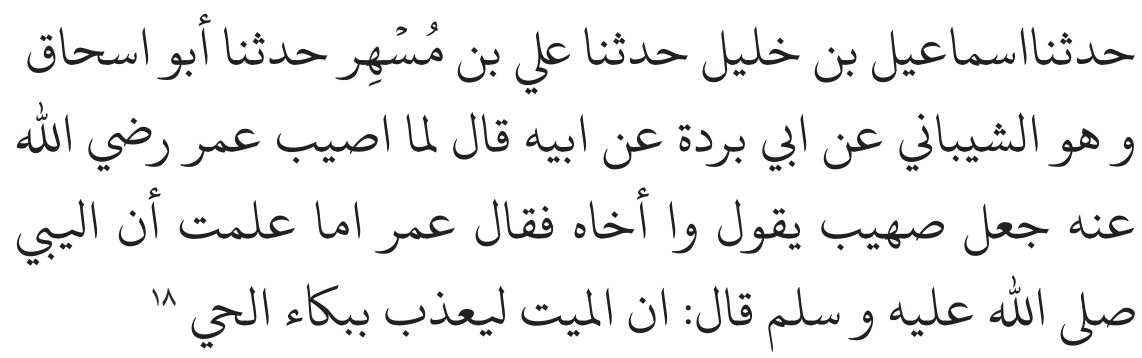

"Ismail bin Khalil menyampaikan hadits kepada kami, 'Ali bin Mushir menyampaikan hadits kepada kami, Abu Ishak, seorang (tua) yang berambut putih umenyampaikan hadits kepada kami, dari Abu Burdah, dari ayahnya, dia berkata: 'ketika Umar terkena musibah (ditusuk), Shuhaib dan saudaranya berkata, Umar berkata, 'apakah kalian tidak tahu bahwa Nabi saw (pernah) bersabda' sesungguhnya mayit akan disiksa karena (akibat) tangisan orang yang masih hidup." (HR. Bukhari dan Muslim)

حدثنا عبدان حدثنا عبد الله أخبرنا ابن جريج قال أخبرني عبد الله بن عبيد الله بن أبي مُليكة قال توفيت ابنة لعثمان رضي

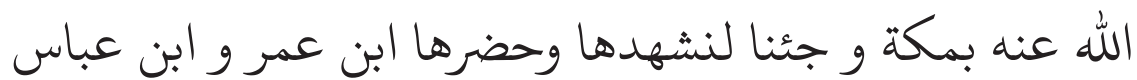
رضي الله عنهما و الي لجالس بينهما او قال جلست المى احدهما ثم جاء الأخر فجلس الى جنبي فقال عبد الله بن عمر رضي الله عنهما لعمرى بن عثمان الا تنهى عن البكاءفان رسول الله صلى الله عليه و سلم قال ان الميت ليعذب ببكاء أهله عليه ...

${ }^{18}$ Abû 'Abdulâlh Muhammad bin Ismâîl, Shahîh al-Bukhârî. 81 
Hadits-hadits tentang rasulullah saw menangis karena kematian kerabat dan sahabat beliau.

a. Rasulullah menangis saat kematian putri beliau

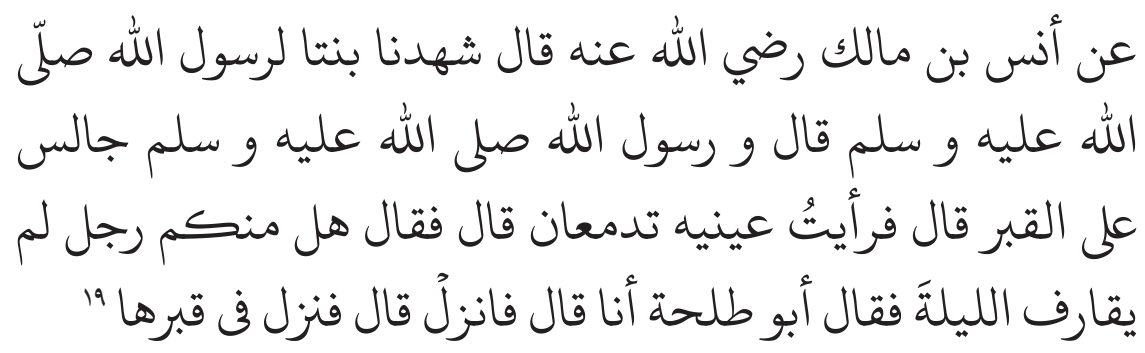
"Dari Anas bin Malik r.a. dia berkata, "Kami menyaksikan jenazah putrid Rasulullah SAW, (Anas berkata melanjutkan ceriata) dan nabi duduk di atas kubur, (Anas berkata melanjutkan cerita) dan aku melihat kedua mata beliau berlinang air mata, (Anas berkata melanjutkan cerita) kemudian Rasulullah SAW bersabda, "Apakah terdapat laki-laki dia antara kalian yang tidak melakukan dosa tadi malam?" Abu Thalhah berkata, "Aku (wahai Nabi), maka turunlah", lalu dia turun ke kubur puteri beliau. (HR. Bukhari)

عن أنس رضي الله عنه قال: شهدت بنتا للنبي صلى الله عليه وسلم تدفن و رسول الله صلى الله عليه و سلم جالس عند القبر

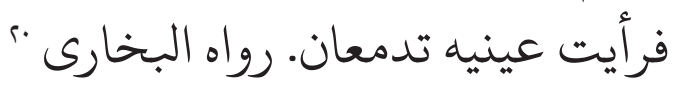

"Dari Anas r.a. berkata: saya menyaksikan putrid Nabi saw dikubur dan Rasul saw duduk dekat kuburan lalu aku lihat kedua mata beliau berlinang air mata." (HR Bukhari)

b. Rasulullah menangis saat kematian putra belia, Ibrahim.

عن أنس بن مالك رضي الله عنه قال دخلنا مع رسول الله صلى الله عليه وسلم على أبي سيف القين وكان ظئرا لأبراهيم عليه

19 Abû 'Abdulâlh Muhammad bin Ismâill, Shahîh al-Bukhârî 80

${ }^{20}$ Ibn Hajar al-Asqalânî, Bulûgh al-Marâm min Adillah al-Ahkâm, (Bairût; li al-Thabâ'ah wa al-Nasyr wa al-Tauzî̀, t. t.), h. 117 Selanjtunya disebut Bulûgh al-Marâm 
السلام فأخذ رسول الله صلى الله عليه و سلم ابراهيم فقبّله و

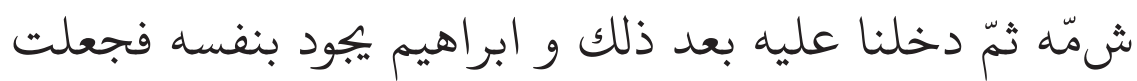

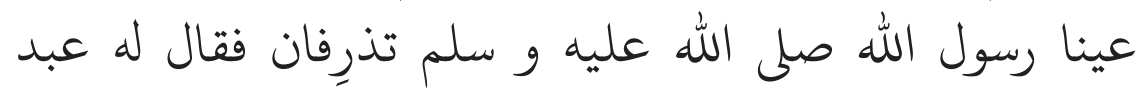

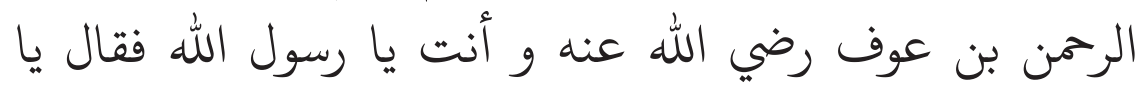

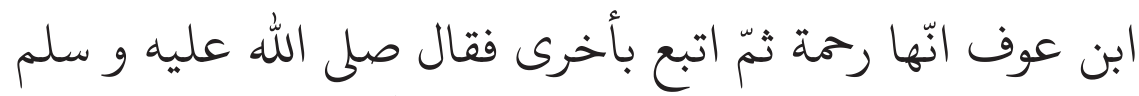

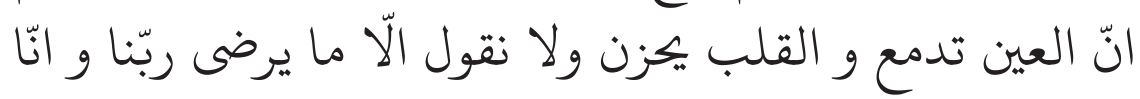
بفراقك يا ابراهيم لمحزونون رواه موسى عن عن سليمان بن المن المغيرة

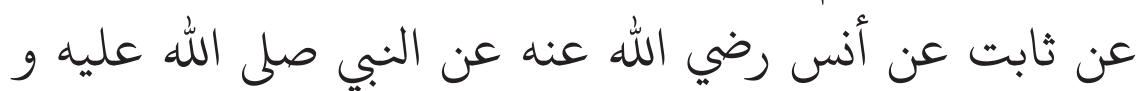
سلم " سابت "Dari Anas bin Malik dia berkata, "Kami bersama Rasulullah masuk ke rumah Abu Saif al-Qayni yang merupkan pengasuh Ibrahim [putra Rasulullah], kemudian Rasulullah saw mengambil Ibrahim lalu mengecup dan menciumnya, kami masuk ke tempat [Ibrahim] dan Ibrahim dalam keadaan sakaratul maut sementara mata Rasulullah saw berlinang air mata. [Melihat hal tersebut] Abdurrahman bin 'Auf berkata, "Engkau, wahai Rasulullah [menangis?] Rasul menjawab, "Wahai Ibn Auf, ini adalah rahmat." Kemudian ia berkata "Mata menangis, hati bersedih, dan kami mengucapkan hanya apa yang Allah ridha, dan kami sangat bersedih atas kepergianmu, Ibrahim". (HR. Bukhari dan Muslim)

\section{c. Rasulullah menangis karena kematian cucu beliau}

عن أسامة بن زيد قال كنّا عند النبيّ صلى الله عليه و سلم

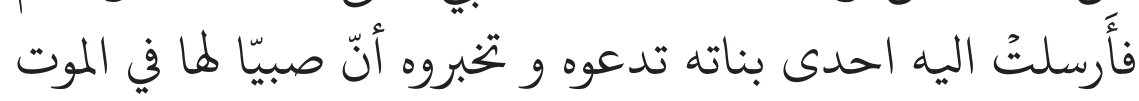

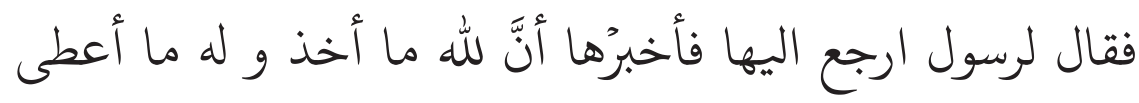

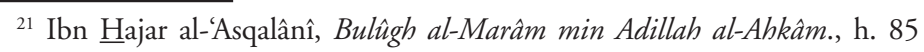




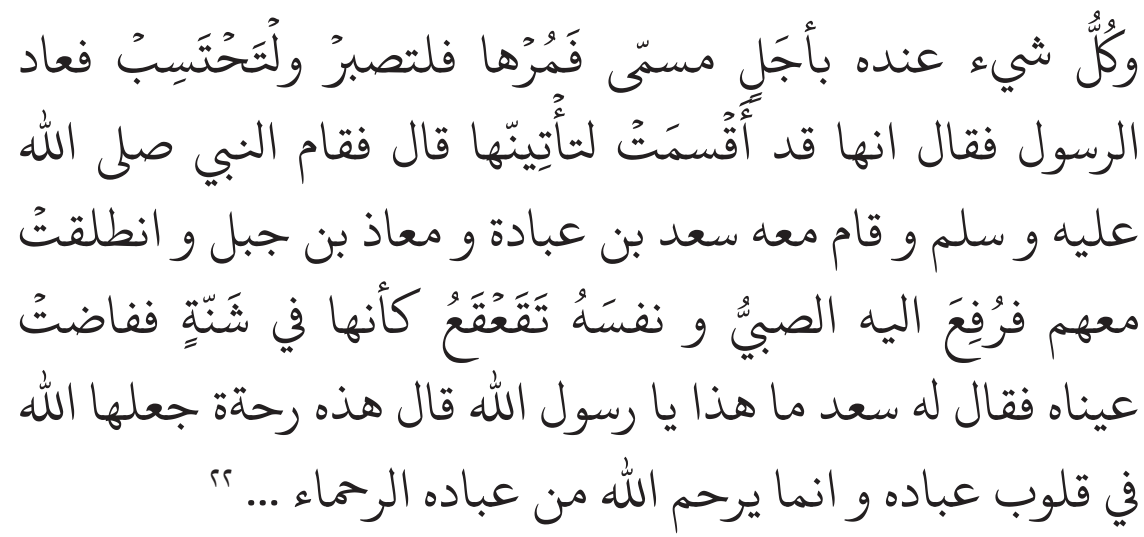

"Dari Usamah bin Zaid dia berkata, 'kami sedang berada di dekat Rasul saw, ketika salah seorang putri beliau mengirm utusan untuk memanggil beliau dan member kabar bahwa anak putri beliau sedang menghadapi maut, lalu Rasul bersabda kepada utusan tersebut, 'kemablilah dan kabarkan kepadanya bahwa apa yang Allah ambil dan berikan adalah milik-Nya, segala sesuatu di sisi-Nya adalah memiliki batas waktu. Suruh dia bersabar dan mengharap pahala'. Utusan itu kembali dan berkata, 'dia berjanji memenuhi pesan-pesan tersebut'. Lalu Nabi saw berdiri diikuti Saad bin 'Ubadah dan Mu'adz bin Jabal. Akupun (Usamah bin Zaid) ikut berangkat bersama mereka. Kepada beliau anak putrid beliau diserahkan dan jiwannya bergolak seperti dalam qirbah (tempat air dari kulit) tua. Kedua mata Rasul meneteskan air mata. Lalu Sa'ad bertanya, 'apa arti air mata itu wahar Rasul?' Rasul menjawab, 'ini adalah rahmat yang Allah swt berikan kepada hati hambanya. Sesungguhnya Allah mengasihi para hambaNya yang pengasih.” (HR. Bukhari dan Muslim)

\section{Penyelesaian Dua Hadits yang Bertentangan Menggunakan Metode Mukhtalif al-Hadîts}

Hadits 'umar bin Khattab dan Ibn 'Umar yang menyatakan "mayit akan diazab karena tangisa keluarga" bertentangan dengan hadits-hadits yang menyatakan bahwa Rasulullah saw menangis saat keluarga dan sahabat beliau wafat.

Dalam studi Mukhtalalif al-Hadits, kedua hadits tersebut memenuhi

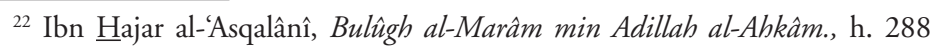


syarat pertentangan sebagai berikut: (a)Pertentangan terjadi dalam satu permasalahan, yaitu menangisi mayit. (b)Pertentangan terjadi pada dua hukum/madlûl, dalam kajian ini terdapat hadits yang menyatakan mayit akan diazab akibat tangisan keluarga dan terdapat hadits bahwa Rasulullah menangis saat kematian kerabatnya.

Dengan demikian, maka penyelesaian pertentangan hadits-hadits tersebut adalah dengan menggunakan salah satu metode Mukhtalif alHadîts, yaitu al-Jam'u wa al-Taufíq:

\section{Penyelesaian dengan al-Jam'u wa al-Taufîq}

Al-Jam'u wa al-Taufí (kompromi) adalah cara yang dapat digunakan untuk mengkompromikan hadits-hadits yang saling bertentangan, salah satunya adalah dengan memaknai hadits atau lafadz-lafadz yang terkandung di dalamnya. ${ }^{23}$ Kata yang paling menjadi penyebab pertentangan adalah al-bukâ yang berarti menangis atau tangisan. Menangis di sini bisa jadi sekedar meneteskan air mata tanpa suara atau bisa juga menangis dengan suara. Pertanyaannya adalah apakah 'menangis/tangisan' pada hadits tersebut mencakup keduanya atau salah satunya?.

Menurut al-Nawawi, ulama telah sepakat bahwa maksud kata al-Bukâ adalah al-Niyâhah yang berarti bukan hanya sekedar mengeluarkan air mata tetapi dibarengi dengan ekspresi atau ungkapan ketidakrelaan akan kematian si mayit. Hal ini sesuai dengan sabda Nabi saw:

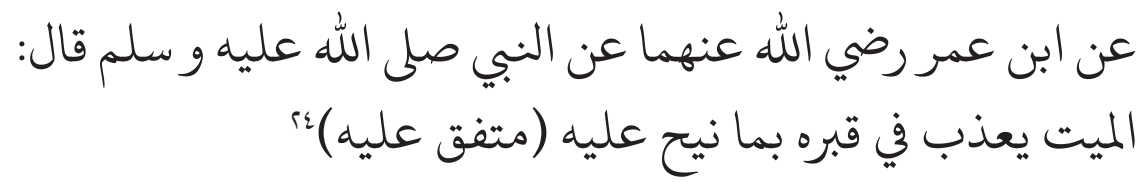

"Dari Ibn 'Umar r.a. dari Nabi saw, bersabda ia: mayit diazab di dalam kuburnya karena diratapi” (HR. Bukhari dan Muslim)

Menurut Ibnu Qudâmah, kata al-Bukâ dimaknai dengan tangisan yang tidak dibenarkan oleh syari'ah yaitu meraung dan meratap. Adapun tangisan yang tidak seperti itu adalah tangisan yang dibolehkan menurut mayoritas ulama. ${ }^{25}$

${ }^{23}$ Lihat Hakimah Hafizhi, Mukhtalif al-Hadîts,(al-Jazâir:Wazarah al-Tálîm al-Alî, 2010), h. $46-56$

${ }^{24}$ Ibn Hajar al-Asqalânî, Bulügh al-Marâm min Adillah al-Ahkâm h. 116

${ }^{25}$ Abû Muhammad Muwaffiq al-Dîn 'Abdullâh bin Ahmad bin Muhammad bin Qudâmah, 
Menurut al-Bukhârî ${ }^{26}$ — sebagaimana dikutip oleh Ibn Hajar dalam Fath al-Bâri-maksud dari hadits "mayit akan diadzab karena tangisan keluarganya" adalah meratap yang merupakan kebiasaan si mayit saat hidupnya sehingga saat ia mati perbuatan meratap tersebut diikuti oleh kerabat atau keluarganya. Dengan demikian si mayit telah memberikan contoh buruk saat hidupnya yang diikuti oleh orang-orang setelahnya. ${ }^{27}$

Beberapa imam ahli hadits memasukan bab meratapi mayit menjadi bab tersendiri karena terdapat bab dibolehkannya menangisi mayit. Contohnya adalah Imam Nawawi memuat bab jawaz al-bukâ ala al-mayit bi ghairi nadbin wa lâ al-Niyâhah, ${ }^{28}$ Abû Dâud memuat Bab fî al-Nauh (bab tentang meratap), ${ }^{29}$ al-Nasâ'i memuat Bâb al-Niyâhah 'ala al-Mayit, dan Ibn Majah memuat bab Mâ Jầa fi al-Mayit Yủadzabu bima Nîha 'alaihi (bab tentang Mayit Diadzab karena Diratapi) ${ }^{30}$

\section{Penutup}

Pertentangan antara hadits-hadits tersebut dalam satu konteks permasalahan, jika terjadi dalam konteks yang berbeda maka tidak disebut sebagai hadits yang bertentangan. Terdapat pertentangan antara dua hukum, yaitu ada yang menunjukan sesuatu yang haramdan ada yang menunjukan sesuatu yang halal. Pertentangan hadits Umar dan Ibn "Umar mengenai "mayit diazab karena tangisan keluarga" dengan hadits "Rasulullah menangis saat keluarga dan sahabat beliau wafat" diselesaikan dengan cara Al-Jam'u wa al-Taufiq (dikompromikan) dengan memaknai al-bukâ (menangis) menjadi al-Niyahah (meratap). Dengan kompromi tersebut maka tidak ada pertentangan antara hadits "mayit diazab karena tangisan keluarga" dengan hadits "Rasulullah menangis saat keluarga dan sahabat beliau wafat" Maka menangis tengan sekedar berurai air mata

al-Mughnî fî Fiqh al-Imâm Aḥmad bin Hanbal al-Syaibânî, (Kairo: Jijr li al-Thabâ’ah wa al-Nasyr, 1992), cet. ke-II, jilid III, h. 495

${ }^{26}$ Imam al-Bukhari memiliki nama lengkap Muhammad bin Ismail bin Ibrahim. Julukannya adalah Abu Abdillah. Ia wafat di Samarkand pada $256 \mathrm{H}$.

${ }^{27}$ Abû Fadhl Ahmad bin 'Alî bin Muhammad bin Ahmad bin Hajar al-Asqalânî, Fath alBâri bi Syarh Shahîh al-Bukhârî, (Kairo: Dâr al-Rayyân li al-Turats, 1990), jilid III, h. 152-153

${ }^{28}$ Al-Nawâwî, Riyâdh al-Shîlihîn min Kalàm Sayyid al-Mursalîn, (Kairo: Dâr Ibn al-Jauzî, 2006), cet. ke-I, h. 246

${ }^{29}$ Abû Dûud, Sunan Ab̂̂ Dâud, jilid II, h. 62

${ }^{30}$ Lihat dalam bab II Syaraf al-Qudhât, 'Ilm Mukhtalif al-Hadîts: Ushuluhûu wa Qawâiduhî, (Amman: Al-Jami’ah al-Urduniyyah, 2001) 
tanpa meratap adalah diperbolehkan.

\section{Pustaka Acuan}

Al-'Asqalânî Abû Fadhl Ahmad bin 'Alî bin Muhammad bin Ahmad bin Hajar, Fath al-Bâri bi Syarh Shahîh al-Bukhârî, Kairo: Dâr al-Rayyân li al-Turats, 1990.

, Bulûgh al-Marâm min Adillah al-Ahkâm, Bairût; li al-Thabâ'ah wa al-Nasyr wa al-Tauzî̀, t. t.

, Tahdzîb al-Tahdzîb, Bairut, Libanon: Dâr al-Ihyâ al-Turats al-Arabî, $1413 \mathrm{H} / 1993 \mathrm{M}$.

Al-Mundzirî, Hâfidz, Mukhtashar Shahîh Muslim, Tahqîq: Muhammad Nâshir al-Dîn al-Bânî, Wizârah -al-Awqâf wa al-Syuûni al-Islâmiyyah al-Turats al-Islâmî, 1399 H/1979 M.

Al-Nawâwî, Riyâdh al-Shîlihîn min Kalâm Sayyid al-Mursalîn, Kairo: Dâr Ibn al-Jauzî, 2006.

Al-Nawâwî, Ibn Syaraf, Taqrîb 'Ulûm al-Hadîts (dengan catatan kaki Tadrîb al-Râwî), Al-Maîinah: al-Maktabah al-'Ilmiyyah, 1972.

Al-Naisabûrî, Abu al-Husain Muslim bin al-Hajjâj al-Qusyairî, Shahîh Muslim, Bairût: Dâr al-Fikr, 1988.

Al-Qudhât, Syaraf, 'Ilm Mukhtalif al-Hadîts; Ushuluhîu wa Qawầiduhû, Amman: al-Jami'ah al-Urduniyyah, 2001.

Al-Sausuwah, 'Abd al-Majîd Muhammad Ismâ'îl, Manhaj al-Taufîiq wa al-Tarjîh bain al-Mukhtalif al-Hadîts wa Atsaruhî fi Fiqh al-Islâmî, Kairo: Jâmi’ah al-Qâhirah, 1992.

Al-Sib'î, Musthafâ, Al-Sunnah wa Makânuhâ fi al-Tasyri al-Islâmî, Bairut: Dâr al-Warrâq, 1419H/ 1998 M.

Al-Syâfi'i, al-Risâlah, Bairût: Dar al-Kutub al-'Ilmiyyah, t.t.

Al-Thahâwî, Syarh Musykil al-Atsâr, Bairut: Dâr -Kutub al-Ilmiyyah, 1995.

Al-Zahrânî, Muhammad bin Mathar, Tadwîn al-Sunnah al-Nabawiyyah Nawyatuhu wa Tathawwuruhî min al-Qarn al-Awwal ila Nihâyah alQarn al-Tâsi’ al-Hijrî, al-Madînah al-Nabawiyyah: Dâr al-Khudlairî, $1419 \mathrm{H} / 1998 \mathrm{M}$.

Bairûm, 'Abd al-Majîd, Ikhltilâf Riwâyat al-Hadîts wa Atsaruhûu fi Ikhtilâf al-Fuqahâ, Amman: al-Jâmi'ah al-Urduniyyah, 1990. 


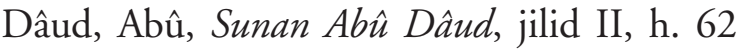

Hafizhi, Hakimah, Mukhtalif al-Hadîts, al-Jazâir:Wazarah al-Ta’lîm al-'Alî, 2010.

Ibn Taymiyyah, Taqî al-Dîn, 'Ilm al-Hadits, Bairût: Dâr al-Kutub alIlmiyyah, 1409 H/1989 M.

Ismâîl, Abû 'Abdulâlh Muhammad bin Shahîh al-Bukhârî, Istanbul: Mausû'ah al-Sunnah; al-Kutub al-Sittah wa Syuruhuhâ, 1113 H/1992 M. 